\title{
MASTERPLAN TEKNOLOGI INFORMASI DAN KOMUNIKASI (TIK) KANTOR PEMERINTAH DESA
}

\author{
Arifin Noor Asyikin ${ }^{(1)}$, Rahimi Fitri(1), Agus Setiyo Budi Nugroho(1) \\ $\underline{\text { arifin@poliban.ac.id }}^{1}$, $\underline{\text { rahimi@poliban.ac.id }}^{2}$, agus sbn@poliban.ac.id ${ }^{3}$
}

(1) Staf Pengajar Progam Studi Teknik Informatika Politeknik Negeri Banjarmasin

\begin{abstract}
The village is the smallest part of the system of administrative governance in Indonesia, which is required to keep abreast of technological developments and improve its ability to manage the administrative data the village population. Currently several villages in southern Kalimantan, there are many uses conventional technologies in system administration services village population. It is very possible impact to village officials and villagers, where frequent human error, as well as a waste of time and cost. Therefore, it needs a system that leads to e-Government to address any problems that occur.

In the implementation of e-Government, the Government needed some kind of strategic planning that is often referred to as the Master Plan for ICT as a base village government in implementing Information Technology and communication. Preparation of Master Plan ICT to the village administration office is expected to be a guide or reference for the village government in determining policies, strategic plans, work programs of ICT, ICT development unit manager, user management, network infrastructure development, ICT infrastructure, and information systems management guidelines

The preparation of the ICT master plan begins with identifying the current condition of the village so that it can be seen readiness of the village at the time of the master plan will be applied, and then determine a strategic plan in ICT include information technology infrastructure, and management ICT
\end{abstract}

Keyword : Master Plan, ICT, IT Governance. Village Government Office

\section{PENDAhULUAN}

Desa merupakan bagian terkecil dari sistem pemerintahan administratif di Indonesia, yang dituntut untuk terus mengikuti perkembangan teknologi dan meningkatkan kemampuannya dalam mengelola data administrasi kependudukan desa. Saat ini beberapa desa di Kalimantan selatan, masih banyak menggunakan teknologi konvensional, seperti: (a) Pencatatan data penduduk desa dalam buku-buku register; (b) Pembuatan surat-surat permohonan yang masih menggunakan mesin ketik. Hal tersebut sangat memungkinkan berimbas kepada perangkat desa maupun penduduk desa, dimana sering terjadi human error, serta pemborosan waktu dan biaya [1]. Oleh karena itu dibutuhkan suatu teknologi informasi yang dapat mendukung proses penyelenggaraan pemerintahan atau yang dikenal secara umum dengan e-Government [2] sehingga mampu meningkatkan pengelolaan informasi [3], hal ini sesuai dengan dengan visi pemerintah melalui kementrian KOMINFO yaitu perlu dibentuk suatu tata kelola dibidang teknologi informasi dan komunikasi (TIK) yang sesuai dengan standart $[4,5]$, yang manfaatnya harus dapat dirasakan secara merata oleh seluruh rakyat Indonesia.

Dalam rangka Penerapan teknologi informasi yang dapat mendukung $e$ Government dan tata kelola TIK di pedesaan maka diperlukan suatu perencanaan strategis TIK yang matang dan menyeluruh sehingga penerapan TIK bisa berjalan sesuai dengan fungsinya dan dapat membantu menyelesaikan permasalahan yang muncul pada saat telah diimplementasikan [1].

Perencanaan Strategis TIK dalam pengembangan e-government digunakan untuk menyesuaikan antara kebutuhan strategi bisnis organisasi pemerintahan desa dan strategi TIK sehingga mendapatkan nilai tambah dari suatu organisasi pemerintahaa. Tahapan Proses identifikasi kebutuhan informasi dalam perencanaan Strategis Sistem Informasi terlebih dahulu dimulai dari lingkungan organisasi yang memuat visi, misi, dan tujuan organisasi, dilanjutkan kepada identifikasi terhadap lingkungan internal dan eksternal organisasi, serta identifikasi internal dan eksternal TIK lingkungan organisasi [2] kemudian dilanjutkan dengan menganalisa 
kebutuhan perangkat lunak maupun perangkat keras TIK dan optimalisasi menyangkut pemanfaatan tepat guna perangkat komputer (Perangkat keras dan perangkat lunak) guna menunjang pelayanan publik di kantor pemerintahan desa.

Penyusunan Master Plan TIK untuk kantor pemerintahan desa diharapkan dapat menjadi pedoman atau acuan pemerintah kota dalam menentukan kebijakan, rencana strategis, program kerja TIK, pengembangan unit pengelola TIK, manajemen pengguna, pengembangan infrastruktur jaringan, Infrastruktur TIK , Panduan pengelolaan Sistem informasi, sehingga kantor pemerintahan desa dapat memberikan layanan public yang cepat, tepat sasaran dan melaksanakan visi pemerintah yang tertuang dalam yaitu Inpres No. 3 tahun 200 yaitu menuju good government [5].

Master Plan TIK adalah suatu perencanaan jangka panjang dalam pengembangan sistem informasi di perusahaan, yang dengan baik mampu menterjemahkan keinginan baik dari pengguna (System User), maupun dari manajemen (System Owner) perubahanperubahan yang terjadi di dalam organisasi maupun di luar organisasi [6, 7]. Beragam metode yang dapat digunakan untuk sebagai teknik dan metode analisis yang digunakan untuk menyusun masterplan TIK diantara nya yaitu metode SWOT [8], menggunakan kerangka kerja COBIT [9, 10], Analisis Critical Success Factor (CSF) dan Political, Economic, Social and Technology (PEST) [7].

\section{METODE PENELITIAN}

Mengingat pengembangan masterplan ini merupakan sebuah transformasi dari manual menuju terkomputerisasi maka dalam penyusunan dibutuhkan upaya-upaya sistematis yang menyangkut subyek, obyek dan metoda yang terkait dengan proses transformasi tersebut.

Dalam penelitian ini akan melalui berapa tahapan pengerjaan yaitu dimulai dengan melakukan assessment terhadap kondisi pelaksanaan atau penerapan TIK saat ini pada berjalan di perkantoran desa meliputi proses bisnis, penggunaan system informasi,

penggunaan teknologi informasi, SDM (manajemen dan organisasi $\mathrm{SI} / \mathrm{TI}$ ), hasil dari assessment selanjutnya digunakan untuk menentukan rancangan usulan system baru yang ideal dengan menggunakan TIK. Selanjutnya adalah mencari 'gap' dari kondisi yang sedang berjalan dengan system usulun yaitu yaitu kesenjangan yang ada antara kondisi ideal yang ingin dicapai, kondisi dimana teknologi informasi akan dapat dipergunakan secara optimal dalam mendukung aktifitas dan proses bisnis kantor pemerintahan desa dengan kondisi yang ada saat ini. Dari hasil penganalisaan ini akan dapat diketahui posisi saat ini untuk mencapai kondisi ideal yang diharapkan, dan mengacu kepada hal ini akan dikembangkan pula langkah-langkah kedepan.

Berdasarkan penilaian kondisi saat ini maka dapat disusun rekomendasi yang berisi saran dan masukan atas temuan-temuan yang telah terjadi. Saran tersebut nantinya dapat digunakan sebagai petunjuk bagi para pembuat kebijakan dalam hal penyusunan kebijakan TI yang dibutuhkan terkait proses bisnis kantor pemerintahan desa, rekomendasi SDM dan organisasi TIK, rekomendasi arsitektur system informasi, rekomendasi arsitektur dan infrastruktur teknologi informasi dan rekomendasi arsitektur jaringan.

Seluruh rekomendasi yang diberikan digunakan untuk menyusun master plan TIK kantor pemerintahan desa yaitu berupa pemetaan kebutuhan sesuai dengan misi, visi, strategi, dan sasaran organisasi desa. Selanjutnya adalah penyusunan road map dimana pada tahapan ini dilakukan suatu perencanaan bagaimana proses transformasi dari kondisi yang ada sekarang menuju kondisi masa mendatang yang akan dituju oleh kantor pemerintahan desa.

Deskripsi langkah-langkah penyusunan master plan TIK kantor pemerintahan desa ditunjukkan seperti gambar 1 berikut ini.

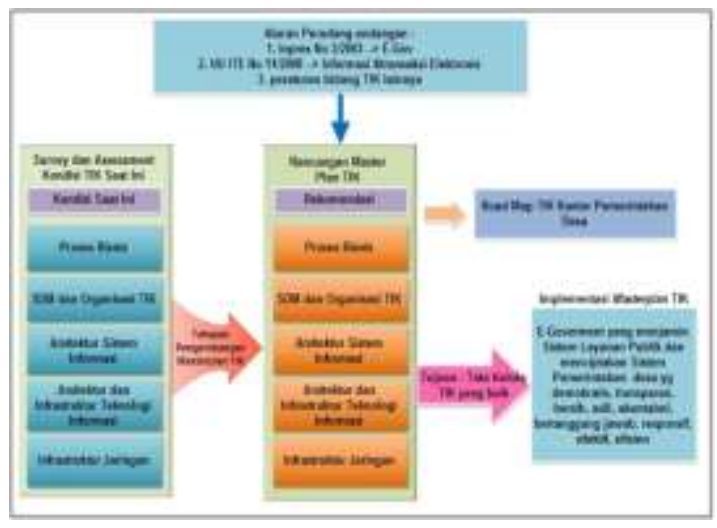

Gambar 1. Langkah-langkah penyusunan Master Plan TIK

Dalam Penelitian ini desa yang akan dijadikan pilot project dalam implementasi Master plan TIK kantor pemerintahan desa adalah desa bamban selatan kecamatan kandangan Hulu 
sungai selatan provinsi Kalimantan selatan, yang selanjutnya akan diikuti oleh desa-desa lainnya.

\section{HASIL DAN PEMBAHASAN}

\section{Penilaian Kondisi Kantor Pemerintahan Desa Saat Ini.}

Pada tahapan awal, kegiatan penelitian yang dilakukan adalah penilaian kondisi kantor pemerintahan desa saat ini. Dalam pengambilan data dilakukan berdasarkan dua jenis pendefinisian yang terdiri dari :

1. Pendefinisian rencana strategi teknologi informasi (TI) dan Kuisioner yang digunakan untuk Pendefinisian rencana strategi teknologi informasi ( $\mathrm{TI}$ ) disusun berdasarkan Kerangka Kerja COBIT 4.1 Proses TI Domain Plan and Organise (PO) 1.

2. Pendefinisian Arsitektur Informasi, Infrastruktur dan Personil TI. Kuisioner yang digunakan untuk pendefinisian arsitektur informasi disusun berdasarkan Kerangka kerja COBIT 4.1 sub domain proses Menentukan Arsitektur informasi (PO2), dan pendefinisian infrastuktur dan personil $\mathrm{TI}$ disusun menggunakan Kerangka kerja COBIT 4.1 sub domain Pendefinisian proses $\mathrm{TI}$, organisasi dan relationship (PO4)

Berdasarkan hasil Hasil penilaian kondisi kantor desa saat ini maka tingkat kematangan proses $\mathrm{TI}$ atau tingkat kesiapan desa berdasarkan acuan domain PO 1 kerangka kerja COBIT tentang pendefinisian rencana strategis $\mathrm{TI}$ berada pada nilai /level kematangan 0.88 , domain PO 2 tentang menentukan arsitektur informasi berada pada nilai/ level kematangan 0.66 , dan domain $\mathrm{PO} 4$ tentang proses $\mathrm{TI}$, organisasi $\mathrm{TI}$ dan hubungannya berada pada nilai/ level kematangan 0,85 . Dari ketiga domain proses $\mathrm{TI}$ tersebut tingkat kematangan dari kantor pemerintahan desa bisa dikatagorikan pada level 1 (initial/Ad Hoc) yang artinya Terdapat bukti bahwa perusahaan mengetahui adanya permasalahan yang harus diatasi. Bagaimanapun juga tidak terdapat proses standar, namun menggunakan pendekatan ad hoc yang cenderung diperlakukan secara individu atau per kasus. Secara umum pendekatan kepada pengelolaan proses tidak terorganisasi.

Pada kantor pemerintahan desa masih sangat minim SDM dan infrastruktur khususnya yang berhubungan dengan Teknologi Informasi dan Komunikasi (TIK), sehingga masih sangat diperlukan pengembangan lebih lanjut

\section{Penyusunan Master Plan TIK}

a. Visi Misi Kantor Pemerintahan Desa Bamban Selatan

Teknologi informasi dan komunikasi merupakan bagian yang tidak terpisahkan dari bisnis. Oleh karena itu rencana strategis TIK harus sesuai dengan rencana strategis kantor pemerintahan desa bamban selatan.

Berikut ini adalah visi dan misi desa bamban selatan kecamatan kandangan kabupaten hulu sungai selatan provinsi Kalimantan selatan.

1. Visi

Mewujudkan desa bamban selatan menjadi desa mandiri melalui bidang pertanian dan perkebunan

2. Misi
a. Memperbaiki dan menambah dibutuhkan untuk meningkatkan SDM melalui pendidikan formal dan informal
b. Bekerja sama dengan petugas penyuluh lapangan untuk meningkatkan hasil pertanian
c. Meningkatkan usaha pertanian
d. Meningkatkan dan mengelola pendapatan asli desa
e. Mewujudkan pemerintah yang baik dan bersih melalui pelaksanaan otonomi daerah.

\section{b. Analisis SWOT}

Selain melakukan analisis data yang komprehensif terhadap hasil survei, agar hasil penyusunan Master Plan Teknologi Informasi dan Komunikasi (TIK) di Kantor pemerintahan desa bamban selatan dapat mencapai kondisi ideal yang diharapkan maka perlu dilakukan suatu analisis yang mendalam dengan metode SWOT. Pada bagian ini akan memperlihatkan faktor-faktor internal yang dapat saling mempengaruhi yaitu strength (kekuatan) dan weakness (kelemahan) serta factor-faktor internalyang juga saling mempengaruhi yaitu Opportunities (peluang) dan Threats (ancaman). Selanjutnya menentukan strategi yang disusun berdasarkan parameter-parameter terkait yaitu stategi SO, Strategi WO, strategi ST dan strategi WT. Gambar 2 berikut ini adalah swot pada kantor pemerintahan desa bamban selatan. 


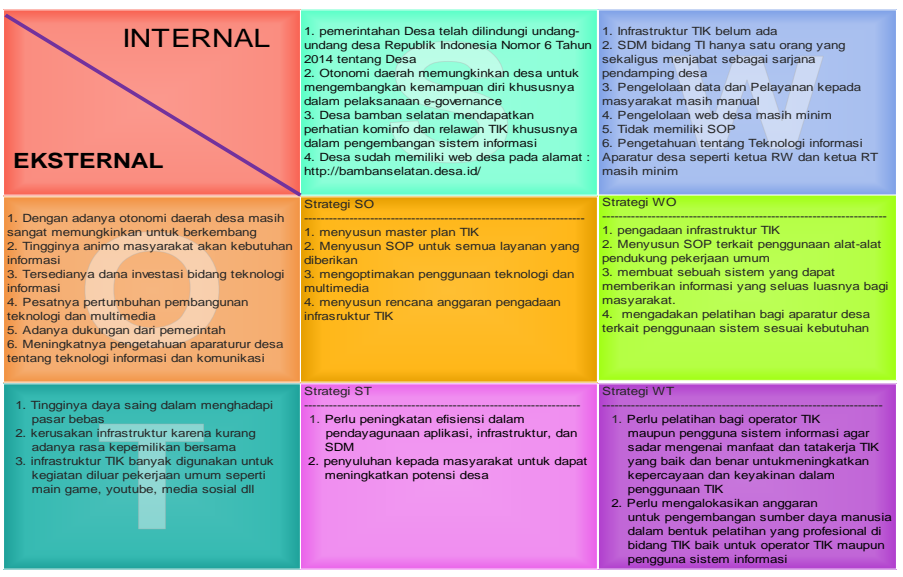

Gambar 2. SWOT Kantor Pemerintahan desa Bamban Selatan

\section{c. Rekomendasi Pengembangan Sistem Informasi, Teknologi Informasi dan Komunikasi}

Berdasarkan analisa yang telah dilakukan, maka rekomendasi terkait konten minimum dari pengembangan sistem informasi, teknologi informasi dan komunikasi adalah sebagai berikut :

\section{Website Desa}

Website desa merupakan salah satu strategi di dalam melaksanakan egovernment secara sistematik yang melalui tahapan yang realistic dan terukur. Pembuatan website desa merupakan tahapan pertama dalam pengembangan e-government dengan sasaran agar masyarakat dapat memperoleh akses informasi dan layanan kantor pemerintahan desa.

2. Aplikasi Sistem Informasi dan Administrasi Pedesaan (SIAP)

Merupakan aplikasi yang diperuntukan bagi layanan Administrasi di Pemerintahan Desa sesuai dengan amanat pada Undang Undang Nomor 6 Tahun 2014 tentang Desa, maka Pemerintah Desa berkewajiban untuk memiliki sebuah Sistem Informasi Desa. Sistem Informasi dan administrasi pedesaan diklasifikasikan menjadi :

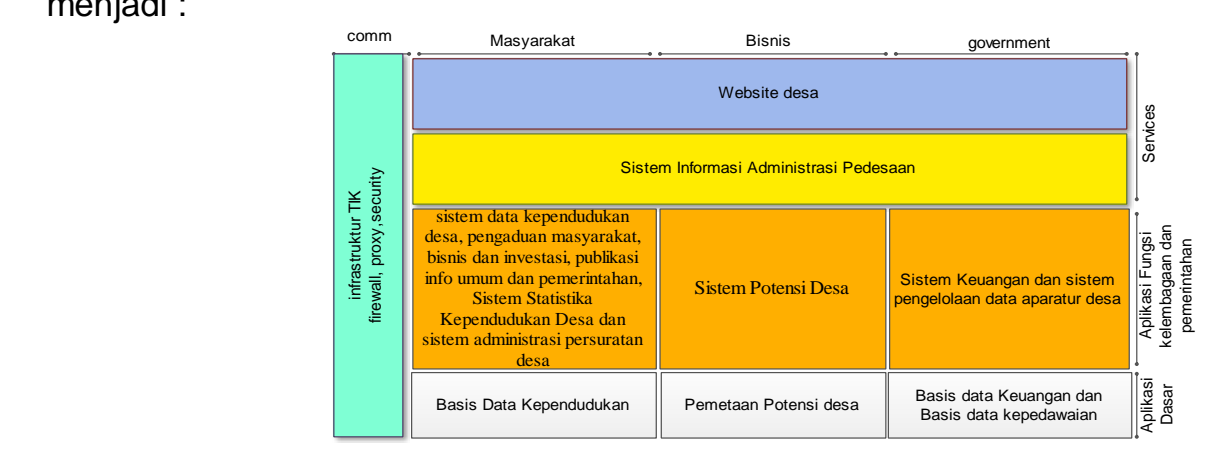

Gambar 2. Peta Solusi Aplikasi e-Government kantor pemerintahan desa
Bidang kelembagaan dengan layanan berorientasi Publik

Untuk bidang ini beberapa layanan yang harus ada didalam system adalah sistem data kependudukan desa, pengaduan masyarakat, bisnis dan investasi, publikasi info umum dan pemerintahan, Sistem Statistika Kependudukan Desa dan sistem administrasi persuratan desa.

- Bidang kelembagaan dengan layanan berorientasi Bisnis

Untuk bidang ini beberapa layanan yang harus ada didalam system adalah Sistem Potensi Desa

- Bidang kelembagaan dengan layanan berorientasi Bisnis

Untuk bidang ini beberapa layanan yang harus ada didalam system adalah Sistem keuangan dan system pengelolaan data aparatur desa.

Sistem aplikasi dikembangkan dengan tujuan untuk memenuhi kebutuhan fungsi kepemerintahan seperti yang telah didefinisikan dan dikelompokkan dalam Kerangka Fungsional Sistem Kepemerintahan tersebut di atas. Berikut ini adalah Peta Solusi Aplikasi e-Government kantor pemerintahan desa. 
Aplikasi SIAP adalah sistem olah data dan informasi berbasis komputer yang dapat dikelola oleh pemerintah dan komunitas desa dalam dua ranah yaitu:

1. Offline

Aplikasi diinstall dalam komputer server di kantor desa dan dioperasikan sebagai server (pusat data) yang bersifat lokal. Oleh karena tidak terhubung ke internet, SIAP offline hanya bisa diakses dalam jaringan local (local area network). Sistem offline ini direkomendasikan untuk diterapkan dalam penggunaan aplikasi SIAP harian. Database dari hasil proses olah data secara offline itu dapat diunggah ke sistem online secara berkala.

2. Online

SIAP akan optimal jika terhubung ke internet sebagai sistem online berbasis web. SIAP online akan otomatis berfungsi juga sebagai website desa. Website desa ini memiliki fungsi yang terbagi dalam dua bagian, yakni bagian depan (front-end) yang bisa diakses oleh publik dan bagian dalam (back-end) yang hanya bisa diakses oleh administrator sistem. Dalam pengembangannya, sistem data informasi ini akanbisa dihubungkan dengan sistem informasi di tingkat supradesa untuk mendapatkan bentuk manfaat yang lebih luas bersama para pihak dari tingkat desa, kabupaten/kota, hingga provinsi, dan kawasan.

Sistem e-Government desa memiliki lingkup fungsi yang cukup besar (menyangkut semua hal yang berhubungan dengan pemerintahan) sehingga dalam proses pengembangannya hampir dapat dipastikan melibatkan banyak vendor, sehingga diperlukan mekanisme komunikasi baku antar sistem, sehingga masing masing sistem aplikasi dapat saling bersinergi untuk membentuk layanan e-Government desa yang lebih besar dan kompleks. Oleh karena itu, dalam membangun aplikasi diperlukan standarisasi kebutuhan pengembangan system aplikasi yang dapat menjamin bahwa komunikasi antar system tersebut dapat dilakukan oleh siapapun vendor pengembang system.

Berikut ini adalah standar kebutuhan system aplikasi yang harus dipenuhi

oleh setiap system aplikasi pada egovernment desa:

1. Reliable

Menjamin bahwa sistem aplikasi akan dapat berjalan dengan handal, robust terhadap kesalahan pemasukan data, perubahan sistem operasi dan bebas bug

2. Scalable

Menjamin bahwa sistem aplikasi akan dapat dengan mudah ditingkatkan kemampuannya, terutama penambahan fitur baru, penambahan user dan kemampuan pengelolaan data yang lebih besar.

3. User Friendly

Menjamin bahwa sistem aplikasi dapat mudah dioperasikan dengan user interface (antar muka pengguna) yang lazim berlaku di pemerintahan.

4. Integrateable

Menjamin bahwa sistem aplikasi mmpunyai fitur untuk kemudahan integrasi dengan sistem aplikasi lain, terutama untuk melakukan transaksi pertukaran data dan informasi antar sistem aplikasi e-government desa

\section{d. Rancangan Infrastruktur Jaringan Komputer di Pedesaan}

Teknologi jaringan komputer saat ini berkembang dengan pesat. Tidak ada satupun tempat di dunia ini yang tidak dapat diakses menggunakan komputer. Berbagai model infrastruktur jaringan komputer dapat dilakukan melalui jaringan media transmisi telpon selular, satelit. Model tersebut dikembangkan dengan tujuan memperoleh kecepatan akses yang tinggi dan dengan biaya pembangunan maupun akses lebih murah. Model ini harus dipikirkan dan disiapkan sebagai model pembangunan jaringan informasi untuk petani.

Berbagai model infrastruktur teknologi jaringan dapat digunakan dengan melihat tujuan yang ingin dicapai yaitu:

1. Individual Akses;

Pada bagian ini

petani secara perorangan atau seti ap rumah di desa memiliki sambungan jaringan komputer. Individual akses ini dapat sangat membantu petani karena setiap saat petani dapat mengakses informasi apapun melalui internet, akan tetapi tidak efisien ditinjau dari sudut ekonomi.

2. Group Akses;

Dimana petani yang tergabung dalam kelompok tani memiliki satu tempat untuk mengakses internet. Group akses secara ekonomi lebih efisien akan tetapi akan mengalami kendala 
jika lokasi tempat akses jauh dari jangkauan tempat tinggal petani itu sendiri. Infrastruktur teknologi transmisi jaringan komputer dibangun atau dirancang dengan melihat kebutuhan dan geografi wilayah nusantara dan dapat dilakukan dengan fasilitas yang sudah dimiliki bangsa ini yaitu antara lain melalui: satelit, jaringan selular, jaringan telpon tanpa kabel (wireless), dan frekwensi radio Pemilihan infrastruktur transmisi tersebut juga perlu dipertimbangkan dari sisi efisiensi ekonomi pembiayaan. Transmisi satelit cukup baik pada tempat yang tidak terjangkau oleh saluran telpon maupun jaringan listrik akan tetapi biaya pembangunan dan operasionalnya cukup mahal.

Berikut ini adalah kebutuhan minimal dari hardware dan software yang harus ada pada kantor desa.

1. Spesifikasi minimal Hardware

a) Intel Pentium/ Celeron Family/ AMD K6/ Athlon/ Duron Family atau processor yang kompatibel.

b) Minimal processor yang diperlukan sebesar 233-MHz

c) RAM $64 \mathrm{Mb}$ (MS Windows), RAM 512 Mb (Linux)

d) Disk space 400 Mb (MS Windows; tidak termasuk sistem operasi), Disk space 2 Gb (Linux; termasuk sistem operasi)

e) Super VGA $(800 \times 600)$ atau dengan resolusi yang lebih tinggi lagi

f) Keyboard dan mouse yang kompatibel

g) Wireless LAN (opsional)

h) Modem SMS (opsional)

2. Spesifikasi minimal Software

- Sistem Operasi:

a) Windows XP, Windows 7, Windows 8 dan lain-lain.

b) Linux Ubuntu, Mint, CentOS, OpernSUSE, Arch, Fedora, Sabayon, Mageia, ROSA dan lain-lain.

c) MAC OS $X$

- Web Server:

a) Web Server OS Windows: Appserv, Wamp, Vertrigo, Easyphp, Xampp dan lain-lain.

b) Web Server OS Linux: Lampp, Apache, Nginx, Lighttpd dan lain-lain.

- Web-browser (yang mendukung html 5 dan css3):

a) Mozilla Firefox v.16

b) Chrome 5 c) Internet Explorer 10

d) Opera 10.6

e) Rancangan Sumber Daya Manusia (SDM) TIK

Untuk menjalankan e-government desa selain membutuhkan infrastruktur, aplikasi juga membutuhkan SDM TIK yang handal. Membangun sumber daya manusia yang handal dalam menjalankan suatu sistem yang berbasis pada suatu teknologi memerlukan waktu dan tenaga yang cukup besar. Proses pengembangan harus dilakukan secara terencana, sistematis, dan berkesinambungan. Peningkatan kapabilitas SDM di bidang TIK harus menjadi salah satu prioritas, kemampuan yang harus dimiliki oleh sumber daya manusia bidang TIK antara lain:

1. Memahami dan menguasai bidang TIK sesuai tupoksi masing-masing jabatan yang ada pada struktur organisasi kantor pemerintahan desa.

2. Memahami di dalam pembuatan perencanaan, proses pengadaan barang dan jasa, pengawasan dan pengendalian penggunaan TIK.

3. Memahami mengenai manajemen perkantoran berbasis elektronis manajemen proyek TIK.

4. Mampu menjadi agen perubahan.

5. Memahami di dalam melakukan komunikasi dan kerjasama (soft skill), karena budaya kerja TIK menuntut budaya kerja lintas sektoral.

Sumber daya manusia (SDM) yang terampil dan kompeten diperlukan untuk mencapai keberhasilan dalam menyelesaikan semua kegiatan, dan untuk membuat keputusan yang benar dan mengambil tindakan korektif yang tepat sasaran

\section{KESIMPULAN}

Berdasarkan dari penelitian yang telah dilaksanakan dan sudah diuraikan dalam analisis SWOT guna penyusunan master plan TIK pada Pemerintahan desa maka dapat disimpulkan sebagai berikut :

1. Penelitian ini menghasilkan analisis penyusunan master plan TIK kantor pemerintahan desa, dimana sumber data dianalisa menggunakan metode analisis SWOT

2. Master plan TIK ini dapat digunakan sebagai acuan bagi kantor pemerintahan 
desa dalam merencanakan, dan mengimplementasikan TIK pada setiap pekerjaan umum aparatur desa.

3. Master plan TIK ini dapat digunakan sebagai acuan bagi kantor pemerintahan desa dalam menyusun rencana pembangunan jangka menengah desa (RPJMD) dan menyusun rencana anggaran pengadaan infrastruktur TIK

\section{DAFTAR PUSTAKA}

[1] A. N. Asyikin, R. Fitri and A. S. B. Nugroho, "Pengukuran Tingkat Kesiapan Kantor Pemerintahan Desa Dalam Penerapan Masterplan Teknologi Informasi Dan Komunikasi (TIK) Perkantoran Desa Menggunakan Kerangka Kerja Cobit 4.1," in Seminar Nasional Hasil Penelitian dan Pengabdian Pada masyarakat (SNHP3M), Jakarta, 2015.

[2] A. B. Setiawan, "Manfaat Perencanaan Strategis Teknologi Informasi Dan Komunikasi Dalam Pengembangan EGovernment," vol. 8, 2013.

[3] Maniah, "Information Technology (IT) Master Plan Badan Geologi Bandung," Bandung, 2011.

[4] Z. A. Hasibuan and H. B. Santoso, "STANDARDISASI APLIKASI EGOVERNMENT UNTUK INSTANSI PEMERINTAH," in Prosiding Konferensi Nasional Teknologi Informasi dan Komunikasi Indonesia, Bandung, 2005.

[5] Inpres_No_3_tahun_2003, "Instruksi Presiden No 3 tahun 2003 Tentang Kebijakan dan Strategis Nasional Pengembangan E-Government," Pemerintah Republik Indonesia, 2003.
[6] A. Amborowati, "Tinjauan Sebuah IT Master Plan (Studi kasus Master Plan Pemerintahan Daerah DKI Jakarta)," 2010.

[7] A. B. Setiawan, "Manfaat Perencanaan Strategis Teknologi Informasi dan Komunikasi dalam Pengembangan EGovernment," vol. Volume 8, no. Manfaat Perencanaan Strategis Teknologi Informasi dan Komunikasi dalam Pengembangan E-Government, 2013.

[8] A. Apriandes, A. Y. Ranius and F. Syakti, "Analisis SWOT Guna Menyusun Rencana Induk E-Government Pada Pemerintahan Daerah Kabupaten Muara Enim," Vols. Vol. 17 No.2 Maret 2013: 1$11,2013$.

[9] A. Nugraha, "AUDIT TATA KELOLA EGOVERNMENT DI PEMERINTAH DAERAH KABUPATEN GARUT MENGGUNAKAN FRAMEWORK COBIT 4.1," Jurnal Thesis Program Magister Sistem Informasi Fakultas Pascasarjana Universitas Komputer Indonesia, Bandung, 2014.

[10] E. Sutomo and Sholiq, "Perencanaan Master Plan Pengembangan SI/TI menggunakan standart COBIT 4.0 (Studi Kasus di STIKOM)," in Prosiding Seminar Nasional Sistem \& Teknologi Informasi (SNASTI), Surabaya, 2007.

[11] Kemkominfo, "Rencana Strategis Kementrian Komunikasi dan Informatika 2010-2014," Kementrian Komunikasi dan Informatika, Jakarta, 2010. 